\title{
MID1 wt Allele
}

National Cancer Institute

\section{Source}

National Cancer Institute. MID1 wt Allele. NCI Thesaurus. Code C75731.

Human MID1 wild-type allele is located in the vicinity of Xp22.2 and is approximately 388 $\mathrm{kb}$ in length. This allele, which encodes E3 ubiquitin-protein ligase Midline-1 protein, plays a role in the modulation of microtubule organization. Mutations in this gene may be associated with the X-linked form of Opitz syndrome. 